Jurnal Mahasiswa BK An-Nur : Berbeda, Bermakna, Mulia

Volume 7 Nomor 2 Tahun 2021

Tersedia Online: https://ojs.uniska-bjm.ac.id/index.php/AN-NUR

p-ISSN. 2460-9722 | e-ISSN. 2622-8297

\title{
HUBUNGAN ANTARA INTERAKSI TEMAN SEBAYA DENGAN PERILAKU BULLYING SISWA KELAS VIII DI SMP NEGERI 13 BANJARMASIN
}

\author{
Hayati Husna ${ }^{1}$, Sultani $^{2}$, Aminah $^{3}$ \\ Universitas Islam Kalimantan Muhammad Arsyad Al Banjari Banjarmasin \\ hayatihusna020@gmail.com / 081953546677
}

\begin{abstract}
ABSTRAK
Penelitian ini dilatarbelakangi oleh perilaku bullying yang kurang begitu diperhatikan dan bentuk tindak lanjut yang kurang membuat efek jera kepada pelaku, karena bullying dianggap tidak memiliki pengaruh yang besar terhadap remaja. Jenis penelitian ini adalah kuantitatif korelasi, dengan populasi 161 siswa maka didapat 115 orang sebagai sampel. Alat pengumpulan data berupa angket interaksi teman sebaya dan angket perilaku bullying yang dibagikan secara online melaui link google form. Uji validitas instrumen dengan membandingkan $r_{\text {hitung }}$ dan $r_{\text {tabel, }}$, sedangkan untuk reliabilitasnya menggunakan rumus Alpha Cronbach dengan bantuan SPSS ver 26 maka didapat koefisien 0.851 pada interaksi teman sebaya dan koefisien 0.922 pada perilaku bullying menggunakan bantuan SPSS.Hasil penelitian menunjukkan interaksi teman sebaya memiliki deskripsi variabel sangat tinggi sebesar $100 \%$ dengan total 115 orang. Sedangkan deskripsi variabel perilaku bullying terdapat kategori rendah sebesar 50,4\% sebanyak 58 orang, kategori sedang sebesar 48,7\% sebanyak 56 orang dan kategori tinggi sebesar 1\% dengan jumla 1 orang. Sehingga dapat disimpulkan bahwa interaksi teman sebaya dengan perilaku bullying memiliki hubungan dengan bentuk negatif dibuktikan melalui uji korelasinal dengan membandingkan nilai signifikansi yaitu $0.00<$ 0.06 yang didapat, dimana nilai korelasi didapat -0.502 maka menghasilkan nilai korelasi berbentuk negatif artinya semakin tinggi variabel Interaksi teman sebaya maka semakin rendah perilaku bullying, sebaliknya bila semakin tinggi perilaku bullying maka semakin rendah interaksi teman sebaya.
\end{abstract}

Kata Kunci: Interaksi, Teman Sebaya, Perilaku, Bullying.

\begin{abstract}
This research is motivated by bullying behavior that is not given much attention and the form of follow-up that does not create a deterrent effect on the perpetrators, because bullying is considered not to have a big influence on adolescents. This type of research is quantitative correlation, with a population of 161 students, then 115 people were obtained as samples. The data collection tools were in the form of peer interaction questionnaires and bullying behavior questionnaires that were shared online via the google form link. Test the validity of the instrument by comparing rcount and rtable, while for reliability using the Cronbach Alpha formula with the help of SPSS ver 26, the coefficient of 0.851 on peer interaction is obtained and a coefficient of 0.922 on bullying behavior using SPSS assistance.

The results showed that peer interaction has a very high variable description of $100 \%$ with a total of 115 people. Meanwhile, the description of the bullying behavior variable contained a low category of 50.4\% as many as 58 people, a medium category of $48.7 \%$ as many as 56 people and a high category of $1 \%$ with the number of 1 person. So it can be concluded that peer interaction with bullying behavior has a negative relationship as evidenced by a correlation test by comparing the significance value, which is $0.00<0.06$ obtained, where the correlation value is -0.502 , resulting in a negative correlation value meaning that the higher the peer interaction variable, then the lower the bullying behavior, on the contrary, the higher the bullying behavior, the lower the peer interaction.
\end{abstract}

Keywords: nteraction, Peers, Behavior, Bullying

Dipublikasikan Oleh :

UPT Publikasi dan Pengelolaan Jurnal

Universitas Islam Kalimantan Muhammad Arsyad Al-Banjari Banjarmasin 


\section{Hayati Husna ${ }^{1}$, Sultani ${ }^{2}$, Aminah $^{3}$ \\ Jurnal Mahasiswa BK An-Nur : Berbeda, Bermakna, Mulia \\ Volume 7 Nomor 2 Tahun 2021 \\ Tersedia Online: https://ojs.uniska-bjm.ac.id/index.php/AN-NUR \\ p-ISSN. 2460-9722 | e-ISSN. 2622-8297}

\section{PENDAHULUAN}

Negara, masyarakat dan keluarga memiliki harapan yang besar untuk mewujudkan pemuda dan pemudi yang bermental tangguh berprestasi dan juga dapat bersaing di era globalisasi. Mereka berharap bahwa pemuda dan pemudi Indonesia yang menjadi penerus bangsa mampu mempertahankan budaya serta kehormatan negara dan agama. Namun pada kenyataannya justru terbalik, banyak sekali pemudapemudi yang masih diusia remaja ini mengalami kasus-kasus yang berat dan tindakan-tindakan agresif seperti yang kerap terjadi dimasa ini adalah tindakan bullying di sekolah baik verbal maupun nonverbal.

Selama ini perilaku bullying yang kurang begitu diperhatikan dan bentuk tindak lanjut yang kurang membuat efek jera kepada pelaku, karena dianggap tidak mempunyai pengaruh yang signifikan atau dianggap besar terhadap remaja. Perilaku dan sikap remaja sangat dipengaruhi oleh perilaku teman sebaya yang ada dilingkungan sekitarnya. Seperti perilaku bullying banyak terjadi dilingkungan sekolah dan teman sebaya yang mempunyai permasalahan disekolah akan memberi dampak buruk bagi temanteman disekolahnya.

Menurut Pradipta dkk (2014) Salah satu tugas perkembangan seseorang di masa remaja yaitu perkembangan sosial. Pada masa bayi sampai anakanak, seorang individu baru mengenal lingkungan yang kecil yaitu keluaga, ketika individu memasuki remaja, maka mereka akan mengenal lingkungan yang tentu lebih luas dan lebih kompleks lagi antara lain lingkungan sekitar rumah, lingkungan sekolah, dan lingkungan lainnya. Interaksi individu pada masa dan usia ini juga semakin meningkat dengan lingkungannya dan mempengaruhi perkembangan individu tersebut.

Interaksi sosial sendiri adalah suatu hubungan individu degan individu yang lainnya, dan bisa mempengaruhi individu lain dan juga adanya hubungan timbal balik diantaranya. (walgito, 2003).

Teman sebaya (peers) merupakan sebuah kelompok sosial yang seringkali diidentifikasikan sebagai kumpulan orang yang mempunyai kesamaan sosial atau yang mempunyai kesamaan ciri-ciri, misalnya seperti kesamaan usia. Teman sebaya memiliki arti yang teramat penting bagi perkembangan pribadi anak. Salah satu fungsi teman sebaya yang paling penting adalah menyediakan sumber informasi dan perbandingan tentang dunia dan keadaan diluar keluarga. Anak-anak mendapat umpan balik tentang kemampuan-kemampuan serta minat dan bakat mereka dari kelompok teman sebaya. (Desmita, 2008).

Menurut Diane dan Papalia (2009) Kelompok teman sebaya adalah sumber kasih sayang, simpati, pengertian, dan tuntutan moral: tempat untuk melakukan eksperimen serta sarana atau wadah untuk mencapai otonomi dan kemandirian dari orang tua. Kelompok teman sebaya merupakan tempat untuk membentuk hubungan dekat dan akrab yang berfungsi sebagai "latihan" bagi hubungan yang mereka bina di masa dewasa.

Mildred B. (dalam dagun, 2002:100) mengemukakan aspek-aspek interaksi sosial teman sebaya, yaitu:

1. Jumlah waktu remaja yang berada di luar rumah, remaja mempunyai kesempatan lebih untuk berbicara dengan bahasa dan persoalan mereka sendiri kepada teman sebayanya.

2. Keterlibatan remaja bermain bersama teman seuianya, remaja menganggap bahwasanya teman sebaya lebih dapat memahami keinginannya dan belajar dalam mengambil keputusan sendiri.

3. Kecenderungan untuk bermain sendiri, remaja yang suka bermain sendiri biasamya introvert, atau bila dalam menghadapi suatu tekanan hanya berperan seagai penonton saja.

4. Kecenderungan bermain peran, remaja berusaha untuk beradaptasi dengan keadaan dimana remaja aktif bermain dengan teman sebayanya. Perkembangan sosial yang meningkat pada remaja, tampak terlihat dalam keinginannya untuk mendapatkan berbagai stimulan luar.

5. Berperan asosiatif, remaja lebih suka bermain dengan teman sebayanya dalam melepaskan diri dari lingkunyan orang tua dengan maksud menemukan jati dirinya.

6. Sikap kerjasama, pada teman kelompok sebaya untuk pertama kalinya remaja menerapkan prinsip hidup bersama, sehingga terbentuk norma-norma, nilai-nilai, dan simbol sendiri.

Menurut Lee (2004) Bullying adalah suatu hal yang mengerikan dan kejam yang dilakukan oleh individu kepada individu atau sekelompok individu. Korban bullying tentu akan merasa sakit atau terhina, malu dan terancam, sedangkan pelaku bullying bahkan bisa saja tidak menyadari perbuatannyanya.

Menurut Edwards (2006) perilaku bullying kerap terjadi pada masa-masa sekolah menengah yang juga termasuk masa remaja. Karena di masa ini remaja mempunyai tingkat egosentrisme yang sangat tinggi. Selain itu masa remaja juga merupakan masa krisis identitas diri.

Dipublikasikan Oleh :

UPT Publikasi dan Pengelolaan Jurnal

Universitas Islam Kalimantan Muhammad Arsyad Al-Banjari Banjarmasin 


\section{Hayati Husna $^{1}$, Sultani ${ }^{2}$, Aminah $^{3}$ \\ Jurnal Mahasiswa BK An-Nur : Berbeda, Bermakna, Mulia \\ Volume 7 Nomor 2 Tahun 2021 \\ Tersedia Online: https://ojs.uniska-bjm.ac.id/index.php/AN-NUR \\ p-ISSN. 2460-9722 | e-ISSN. 2622-8297}

Menurut Wiyani (2012) Istilah bullying berasal dari bahasa Inggris, yang berbunyi "bull" yang artinya banteng. Secara etimologi kata "bully" artinya penggertak, orang yang seringkai mengganggu orang yang lemah. Bullying sendiri dalam bahasa Indonesia disebut "menyakat" yang artinya mengganggu, mengusik, dan merintangi orang lain.

Macam-macam Perilaku Bullying

Yayasan Semai Jiwa Amini (2008: 2) menyatakan tentang aspek aspek perilaku bullying antara lain:

1) Bullying Fisik

Bullying fisik adalah jenis bullying yang kasat mata, karena terjadi sentuhan fisik antara pelaku bullying dan korbannya. Contoh bullying fisik antara lain:

a) Menampar, menjegal, merampas atau mengambil uang/ barang secara paksa.

b) Melempar dengan barang, menghukum dengan berlari keliling lapangan, menghukum dengan cara push up.

2) Bullying Verbal

Bullying Verbal ialah jenis bullying yang dapat dideteksi sebab dapat tertangkap oleh indra pendengaran kita.

Contoh bullying verbal antara lain:

a) Memaki "Goblok Lo", menghina "Gendut Lo", menjuluki "Si Culun", meneriaki, menyoraki.

b) Mempermalukan didepan umum "Hei, kamu kan bukan kelompok kita", menuduh, menebar gosip, memfitnah.

3) Bullying Mental / Psikologis

Bullying Mental / Psikologis adalah yang paling berbahaya karena tidak dapat tertangkap oleh indera penglihatan ataupun indera kita jika kita kurang peka dalam mendeteksinya. Contoh bullying mental/psikologis antara lain:

a) Memandang sinis dan mengucilkan seseorang

b) Mempermalukan di hadapan khalayak umum dan melakukan teror

\section{METODE}

Penelitian ini menggunakan metode kuantitatif korelasional, dengan kerangka berpikir sebagai berikut

Dalam penelitian kuantitatif masalah yang diangkat oleh peneliti harus sudah jelas. Hal pertama yang harus dilakukan adalah mengidentifikasi dan membatasi masalah maka selanjutnya masalah tersebut dirumuskan.

a. Identifikasi Masalah, adalah akar mulanya peneliti melakukan penelitian berdasarkan adanya sebuah masalah lalu diidentifikasi dan dibatasi.

b. Rumusan Masalah, pada umumnya dinyatakan dengan kalimat tanya. Dengan pertanyaan tersebut maka akan dapat memandu peneliti untuk langkah penelitian berikutnyautnya.

c. Landasan Teori, berdasarkan rumusan masalah tersebut selanjutnya peneliti menggunakan berbagai teori untuk menjawabnya.

d. Perumusan Hipotesis, jawaban dari rumusan masalah yang baru menggunakan teori tersebut disebut hipotesis, sehingga hipotesis dapat diartikan sebagai jawaban sementara terhadap rumusan masalah penelitian.

e. Pengumpulan Data, hipotesis yang masih merupakan jawaban sementara kemudian akan dibuktikan kebenarannya secara empiris berdasarkan data dilapangan. Untuk itu peneliti melakukan pengumpulan data yang dilakukan pada populasi dan sampel tertentu menggunakan bantuan pengembangan instrumen yang nantinya juga akan diuji validitas \& reliabilitas.

f. Analisis Data, data yang telah terkumpul selanjutnya dianalisis menggunakan statistik.

g. Kesimpulan, setelah data hasil penelitian diberikan pembahasan, maka selanjutnya dapat disimpulkan berdasarkan data yang telahr terkumpulm dan yang sesuai dilapangan.

Dengan populasi sebanyak 161 dan sampel sebanyak 115 orang dengan teknik pengambilan sampel yaitu simple random sampling. Adapun Variabel Independen (variabel bebas) adalah interaksi teman sebaya.Variabel Dependen (variabel terikat) adalah Perilaku Bullying. Intrumen pengumpul daya yaitu angket dengan teknik pengumpulan data melaui kuisioner online melalui link google form. Menurut Sugiyono (2015) karena pada prinsipnya meneliti ialah melakukan pengukuran, oleh karena itu harus ada alat ukur yang baik.

Adapun skala pengukuran dalam penelitian ini dengan menggunakan model skala Likert. Menurut Sugiyono (2015) skala likert biasa dipakai untuk mengukur sikap, pendapat, dan persepsi seseorang atau sekelompok orang tentang fenomena sosial. Dengan skala likert, maka variabel yang akan diukur dijabarkan menjadi indikator variabel, kemudian indikator itu dijadikan sebagai titik tolak dalam

Dipublikasikan Oleh :

UPT Publikasi dan Pengelolaan Jurnal

Universitas Islam Kalimantan Muhammad Arsyad Al-Banjari Banjarmasin 
Hayati Husna ${ }^{1}$, Sultani $^{2}$, Aminah $^{3}$

Jurnal Mahasiswa BK An-Nur : Berbeda, Bermakna, Mulia

Volume 7 Nomor 2 Tahun 2021

Tersedia Online: https://ojs.uniska-bjm.ac.id/index.php/AN-NUR

p-ISSN. 2460-9722 | e-ISSN. 2622-8297

menyusun item-item instrumen yang dapat berupa pernyataan atau pertanyaan.

\section{HASIL DAN PEMBAHASAN}

Sebelum peneliti melakukan uji prasyarat dan uji hipotesis, maka terlebih dahulu mencantumkan tingkat interaksi teman sebaya dengan perilaku bullying siswa kelas VIII. Penentuan kategori variabel di lihat dari nilai minimal dan maksimal item pernyataan yang telah di sebar kepada responden dimana jumlah item sebanyak 30 dan 34, dengan skor tertinggi 5 dan skor terendah 1.

Dari jumlah sampel 115 orang didapat hasil interaksi teman sebaya berada pada kategori tinggi yaitu 115 orang, 0 untuk sedang dan 0 untuk rendah. Berdasarkan data dari tabel, dapat dihasilkan bahwa 115 siswa kelas VIII di SMP Negeri 13 Banjarmasin memiliki 115 siswa (100\%) interaksi teman sebaya dalam kategori tinggi, sehingga dapat ditarik kesimpulan bahwa mayoritas siswa kelas VIII di SMP
Negeri 13 Banjarmasin telah mampu menjalin hubungan dengan siswa lain dengan baik.

Dari jumlah sampel 115 orang didapat hasil perilaku bullying berada pada kategori rendah dan sedang, dimana kategori rendah sebanyak 58 orang, kategori sedang sebanyak 56 orang dan tinggi sebanyak 1 orang.

Pada uji ini peneliti menggunakan pengujian Kolmogorov Smirnov pada program SPSS Ver 26. Dalam hal ini peneliti melakukan uji normalitas pada nilai Unstandarized Residual (Res_1) untuk interaksi teman sebaya dengan pengambilan keputusan normalitas, jika nilai signifikansi $>0.05$ maka nilai berdistribusi normal dan jika nilai signifikansi $<0.05$ maka tidak normal. Berdasarkan hasil uji normalitas di ketahui nilai signifikansi $0.200>0.05$ maka dapat disimpulkan nilai residual berdistribusi normal.

Tabel 1. Distribusi Variabel Interaksi Teman Sebaya

\begin{tabular}{ccc}
\hline Kategori & Frequensi & Persentase \\
\hline TINGGI & 115 & $100 \%$
\end{tabular}

$\begin{array}{lll}\text { Total Data } & 115 & 100 \%\end{array}$

Berdasarkan tabel diatas dapat disimpulkan bahwa distribusi variabel interaksi teman sebaya yang mana sebanyak 115 siswa berada pada kategori tinggi., 0 orang pada kategori sedang dan 0 orang pada kategori rendah, dan dapat dilihat dari digram pie sebagai berikut :

\section{Interaksi Teman Sebaya}

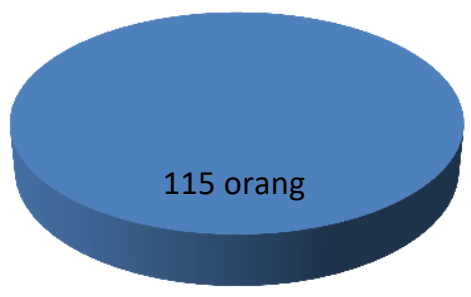


Hayati Husna ${ }^{1}$, Sultani ${ }^{2}$, Aminah $^{3}$

Jurnal Mahasiswa BK An-Nur : Berbeda, Bermakna, Mulia

Volume 7 Nomor 2 Tahun 2021

Tersedia Online: https://ojs.uniska-bjm.ac.id/index.php/AN-NUR

p-ISSN. 2460-9722 | e-ISSN. 2622-8297

Tabel 2. Deskripsi Data Variabel Perilaku Bullying

\begin{tabular}{lcc}
\hline Kategori & Frequensi & Persentase \\
\hline RENDAH & 58 & $50.4 \%$ \\
SEDANG & 56 & $48.7 \%$ \\
TINGGI & 1 & $.9 \%$ \\
\hline Total Data & 115 & $100 \%$ \\
\hline
\end{tabular}

Berdasarkan data dari tabel ini dapat disimpulkan bahwa terdapat 58 orang termasuk kategori rendah dalam perilaku bullying, dan terdapat 56 orang termasuk dalam kategori sedang dalam perilaku bullying juga terdapat 1 orang kedalam kategori tinggi dalam perilaku bullying.

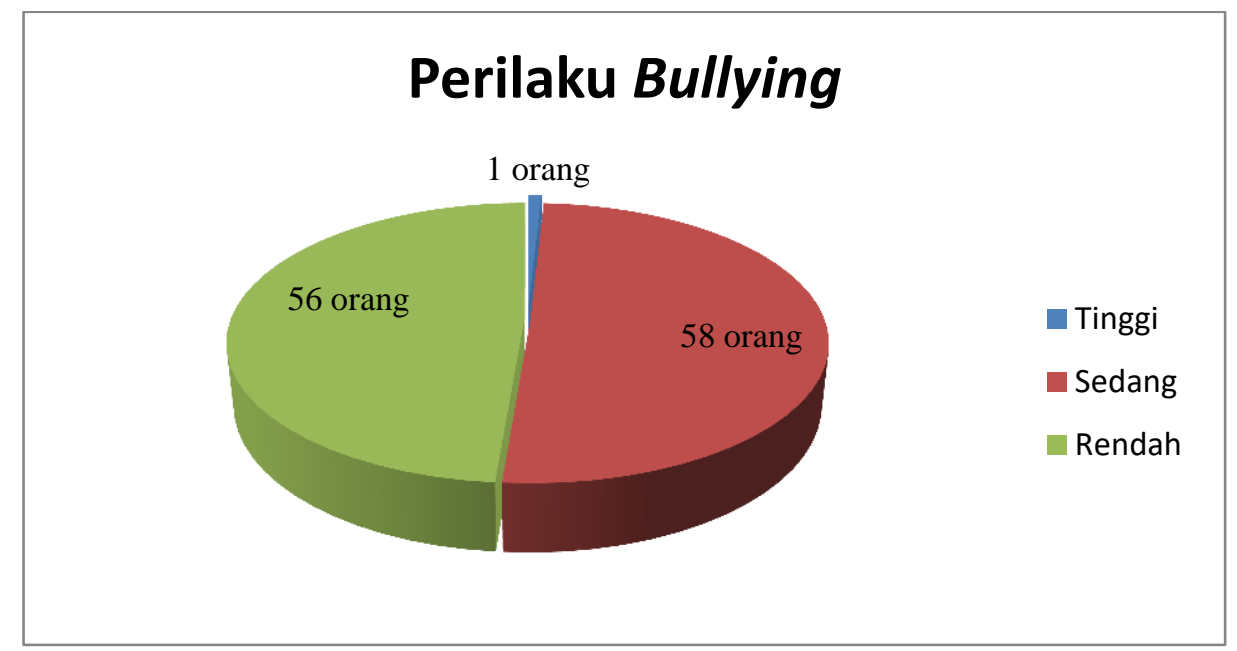

Berdasarkan data diatas dapat disimpulkan bahwa distribusi variabel perilau bullying terdapat 3 kategori distribusi, yaitu distribusi tinggi sebanyak 1 orang berada dapa persentase $9 \%$, kategori sedang sebanyak 56 orang dengan persentase $48,7 \%$ dan juga kategori rendah sebanyak 58 orang dengan jumlah persentase $50,4 \%$, dan dapat dilihat melaui diagram pie diatas sebagai berikut :

Adapun untuk uji prasyarat dilakukan beberapa macam pengujian yaitu pengujian normalitas dan uji linearitas, kemudian dilanjutkan dengan uji korelasional.

Pada Uji normalitas penulis menggunakan pengujian kolnogorov smirnov dengan bantuan program SPSS ver 26. Dalam hal ini peneliti melaukan uji normalitas paa nilai Unstandarized Residual ( Res_1) berdasarkan hasil uji normalitas diketahui nilai signifikansi $0.200>0.05$ maka dapat disimpulkan nilai residual berdistribusi secara normal.

Selanjutrnya pada uji linearitas yang dilakukan untuk mengetahui ada atau tidaknya hubungan secara linear antara variabel bebas dan variabel terikat, pengambilan keputusan ini dapat dilihat dari nilai signifikansi deviation from linearity yang dihasilkan dari uji linearitas dengan bantuan program SPSS ver 26, jika dilhat dari nilai signifikansi defiation from linearity $>0.05$ maka terdapat hubungan yang linear antara variabel bebas dengan variabel terikat dan jika nilai signifikansi defiation from linearity $<0.05$ maka tidak ada hubungan yang linear antara variabel bebas dengan variabel terikat. Berdasarkan nilai signifikansi defiation from linearity $0.380>0,05$ maka artinya terdapat hubungan yang linear antara variabel bebas dengan variabel terikat.

Selanjutnya melakukan uji korelasional dengan membandingkan nilai signifikansi yang ada yaitu $0.000<0.05$ sehingga dapat dikatakan bahwa antar variabel memiliki korelasi dengan bentuk negatif, hal ini ditandai dengan tanda $-0,502$ jadi kesimpulannya variabel $\mathrm{X}$ dan variabel $\mathrm{Y}$ memiliki korelasi dengan derajat korelasinya sedang dan bentuk hubungan negatif.

\section{Dipublikasikan Oleh :}

UPT Publikasi dan Pengelolaan Jurnal

Universitas Islam Kalimantan Muhammad Arsyad Al-Banjari Banjarmasin 


\section{Hayati Husna ${ }^{1}$, Sultani ${ }^{2}$, Aminah $^{3}$ \\ Jurnal Mahasiswa BK An-Nur : Berbeda, Bermakna, Mulia \\ Volume 7 Nomor 2 Tahun 2021 \\ Tersedia Online: https://ojs.uniska-bjm.ac.id/index.php/AN-NUR \\ p-ISSN. 2460-9722 | e-ISSN. 2622-8297}

\section{PENUTUP}

Dari hasil penelitian yang telah diuraikan sebelumnya, maka dapat diambil kesimpulan sebagai berikut, yaitu berdasarkan hasil kategorisasi distribusi interaksi teman sebaya menunjukkan, interaksi teman sebaya pada siswa kelas VIII di SMP Negeri 13 Banjarmasin memiliki kategori tinggi sejumlah 115 siswa dengan presentase $100 \%$, lalu berdasarkan hasil kategorisasi distribusi perilaku bullying menunjukkan, perilaku bullying pada siswa kelas VIII di SMP Negeri 13 Banjarmasin kategori rendah sebanyak 58 orang dengan persentase $50,4 \%$, memiliki kategori sedang berjumlah 56 orang dengan persentase $48,7 \%$ dan kategori tinggi berjumlah 1 orang dengan persentase $9 \%$.

Terdapat hubungan yang signifikan berbentuk negatif antara interaksi teman sebaya dengan perilaku bullying siswa kelas VIII di SMP Negeri 13 Banjarmasin yang dapat dijabarkan dengan nilai koefisien korelasinya sebesar -0.502 . artinya, semakin tinggi interaksi teman sebaya maka semakin rendah perilaku bullying siswa kelas VIII di SMP Negeri 13 Banjarmasin, demikian sebaliknya semakin rendah interaksi teman sebaya maka semakin tinggi perilaku bullying siswa kelas VIII di SMP Negeri 13 Banjarmasin.

\section{REFERENSI}

Dagun, S. M. (2002). Psikologi keluarga. Jakarta: Rineka Cipta.

Desmita, 2008. Psikologi perkembangan. PT Remaja Rosdakarya. Bandung

Diane E. Papalia, (2009) Human Develovment. Edisi 10 Perkembangan . Jakarta: Salemba Humanika

Edwards, D. C. (2006). Ketika Anak Sulit Diatur : Perpaduan Bagi Orang Tua Untuk Mengubah Masalah Perilaku Anak. Bandung: Kaifa.

Lee, C. 2004. Preventing Bullying in School: A Guide for teachers and Other Profesionals. Paul Chapman Publishing: London.

Pradipta, D. A., Hamiyati, H., \& Muhariati, M. (2014). Hubungan Kelekatan Orang Tua dengan Interaksi Sosial antar Teman Sebaya pada Remaja Laki-Laki di SMPN 6 Jakarta. Jurnal Kesejahteraan Keluarga dan Pendidikan, 1(2), 78-84.

SEJIWA ( Yayasan Semai Jiwa Amini). (2008). Bullying: Mengatasi Kekerasan di Sekolah dan Lingkungan). Jakarta: Grasindo.
Sugiyono, (2015). Metode Penelitian Pendidikan. CV. Alfabeta. Bandung

Walgito, B. (2003). Psikologi Sosial Suatu Pengantar. Yogyakarta: Andi Offset

Wiyani, N.A. (2012). Save Our Children From School Bullying. Yogyakarta: Ar-Ruzz Media.

Dipublikasikan Oleh :

UPT Publikasi dan Pengelolaan Jurnal

Universitas Islam Kalimantan Muhammad Arsyad Al-Banjari Banjarmasin 